\author{
Букурие Мустафа (Северна Македонија) \\ Институтот за духовно и културно \\ наследство на Албанците - Скопје \\ bukurie_m2007@hotmail.com
}

\title{
ТРАНСФОРМАЦИЈА НА ЕТНИЧКАТА И ВЕРСКАТА ФУНКЦИЈА НА НАРОДНАТА НОСИЈА НА АЛБАНЦИТЕ ВО МАКЕДОНИЈА ВО ПЕРИОДОТ НА СОЦИЈАЛИЗМОТ
}

\begin{abstract}
Апстракт: Во етнографскиот преглед на Балканот, народната носија вообичаено е претставена како обележје на националниот идентитет, а истовремено и како израз на историското и културното опкружување на народитешто живеат тука. Но, што сеслучува кога етничкиот и националниот идентитет на носијата преминува во културна идентификација на еден систем и време, коешто внесува промени во самата народна носија?

Ваквата состојба на културна и етнографска трансформација во различни историски периоди била условена од различни видови институционални интервенции за изнаоѓње методи и форми, одредени преку законски мерки, дури и забрани со цел законска заштита на ваквите материјални културни добра што му припаѓаат на еден народ. Во овој случај, низ еден хронолошки историски преглед, се прикажува патот на трансформацијата на дел од облековната култура како израз на еден систем, каков што бил системот што го донел „Законот за забрана да се носи зар и фереџе“ објавен во Службен весник на НР Македонија (бр. 1, 12 јануари 1951 г.).

Во поширок контекст, такви закони и денес се носат и во многу други европски земји, коишто на облеката не гледаат како на културен диверзитет или национален идентитет, туку го поставуваат како прашање за едно општество и држава.
\end{abstract}

Клучни зборови: народна носија, поткапа, кече, терлеме, терлик, фереџе, зар.

Македонија минала различни политички системи низ нејзината историја, и во секој од нив имало обиди за наметнување на разни правила и принципи во животот на заедниците во овој регион. Многуте стари фотографии на градските пазари се објективен хронолошки приказ на 
културниот развиток на различните заедници во една средина, поточно и на народната носија, која традиционално била носена низ вековите. Вообичаено, ваквите фотографии се земаат како доказ и историска слика на едно време, раскажувајќи го минатото, а ваквите извори често биле, условно речено, „јаболко на раздорот“во однос на поимањето на културниот и националниот идентитет во овој географски ареал. Разновидноста на народната носија се смета за обележје што е очигледно, но, во исто време, е и дел од определбата на националната и верската припадност на месното население, каде што се мешаат различни култури и етноси, при што се препознаваат националните одлики во народниот костум. Целосната слика не може да се разгледува само од тесно етнолошко гледиште, кога се знае фактот за промените на различни владетели на Балканот, коишто не само што воведувале ново административно и политичко уредување туку влијаеле и на општата културна слика на различните заедници, предизвикувајќи промени. Народните носии ја изразуваат етничката и верската идентификација на нивните носители, и често се случувало преку облеката, или преку делови од неа, да се искажува и социјалната и културната разноликост на населението.

Народите на Балканот се дефинираат според различни основи заради етничко претставување, но основната теза е дека играат „исти ора, јадат иста храна, зборуваат ист јазик и заедно се собираат да реализираат исти активности“ (McCarthy 2017: 47). Во потрага по истото, но, во исто време, и посебното помеѓу народите на Балканот, се креирала сликата на мултикултурализам или, пак, одредување на припадноста врз одредени типови народна носија, често идентификувана преку типичните капи, кои со сигурност се најочигледното обележје на националната идентификација. Во историскиот развој на народната носија на Албанците, најзначајната карактеристика отсекогаш се поврзувала со носењето бело кече, кое станало сенационален симбол, иако низ времето тоа се менувало. Така, турскиот фес се наоѓa на одредени визуелни претстави, но повеќе бил користен како моден детал и не ја отсликувал националната свест кај Албанците. Но, кога капата е израз на препознавање на одредена верска припадност, и тоа се случува во подолг период, во албанскиот етнички простор карактеристично било носењето црна капа, која се носи и ден-денес, и никој не ѝ го знае со сигурност потеклото. Ваквите промени во носијата не може да се гледаат надвор од историските и политичките околности. Влијанието на османлиската или, уште пошироко, на источните култури, кои во подолг временски период се присутни на овие простори, навлегло во културата на секојдневното живеење на балканските заедници.

Важен дел од облеката, којшто во еден историски период бил најмногу употребуван, е фесот, за којшто Петар Скок вели дека го користеле и христијаните и муслиманите: „го носат сите религии“ (Skok 1971: 513). Зборот фес етимолошки е поврзан со името на градот Фес во Мароко, каде што за прв пат се изработувала ваква капа. Фесот е во темноцрвена боја или, 
пак, црна со пискул закачен на средината на врвот. Во 1826 г. фесот станал дел од воената турска униформа, а потоа го носеле и другите. Кај нас, се мисли на овој дел од Балканот, фесот е воведен со ферман од Султан Махмуд II, со кој станал составен дел за администрацијата без разлика на верската припадност (Ibrahimi 2017: 248). Како капа бил познат кај повеќе заедници и се сметал за израз на престиж, што било поизразено во урбаните средини, а речиси воопшто не бил дел од облековната култура во изолираните селски зони. И Албанија не била исклучена од ваквото културно влијание, но по прогласувањето на нејзината независност во 1912 г. состојбата се променила. Андромаќи Ѓерѓи го смета периодот од 1912 до 1944 г. како време на промени во однос на носијата и симболиката. Таа вели дека промените се направени од политички причини, и бесмислено е да се следи турската мода во облеката во време кога се води борба за афирмација и консолидација на албанската држава, која ја објавила и својата независност, бидејќи се

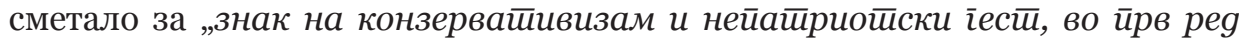
за мажиचе“" (Gjergji 2005: 69). Политичките влијанија и тенденцијата да се создаде една нова модерна држава довеле до тоа да се преземат конкретни чекори и да се носат закони за забрана на носењето на фесот. Така, во 1925 г., во Турција е донесен закон за забрана на носење на фесот како дел од реформите на Кемал Ататурк, којшто сакал да создаде една модерна држава (Dizdar 2005: 270). Во Албанија таквата забрана е донесена неколку години подоцна: „Во 1929 і., се објавува еgна нареgба оg влаgайа за ойфрлање

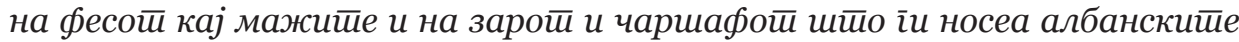
муслимански жени во мнойу ірраgови во земјайа“ (Gjergji 2005: 69). Ова ја покажува сериозноста на прашањето на ориенталната носија, која наеднаш била отфрлена бидејќи била оценета како конзервативна и неприфатлива за едно ново време и визија, коешто било поврзано со приказот за едно модерно општество, па и лаичка држава. Истата ситуација се случувала и во другите земји на Балканот, со идејата за создавање на независни држави, идентификувани преку национални и државни симболи.

Но, Албанците во Македонија доживеаја друга судбина, поминувајќки низ разни режими, какво што било Кралството на СXC (a подоцна Кралството Југославија), војните, окупациите, а потоа создавањето на социјалистичка Југославија, што, исто така, влијаело врз постепеното губење на албанскиот национален симбол, кечейо. Токму симболиката и националната припадност пренесена преку кечето доведе до замената со поинакви капи наместо кечето. Истражувањата и интервјуата со луѓе од постарата генерација сведочат за тоа време. Еден од интервјуираните, роден во 1928 г., го имаше доживеано времето на бугарската окупација и, на прашањето кога се смениле капите, кечето во село Патишка, ми одговори:

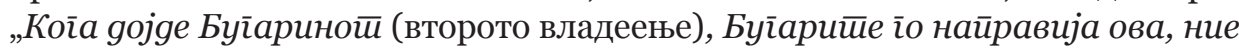

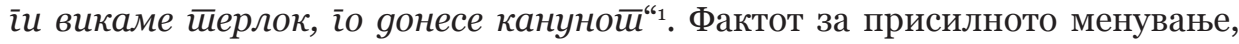
освен преку сведочењата на жителите, може да се следи и низ историските

1 Интервју со Истреф Беќири, с. Патишка (1928 - 2015), реализирано од Ибе Мустафа и Букурије Мустафа, во Скопје, 15 јануари 2012 г. 
пишувања за времето: „Во еgен ӣериоg во Скойје, Албанцииее не можеле

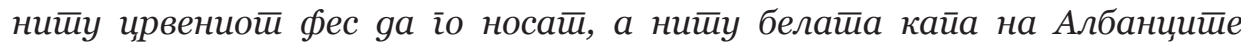

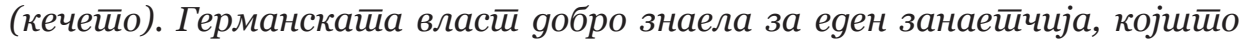
заработиувал во Скойје ӣроgавајќи бели кайи, кој бил уайсен среg бел gен,

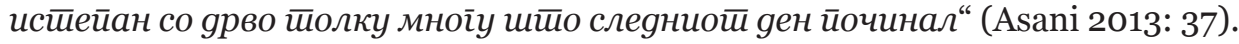
Сликата за Албанецот почнала да се менува, кечето се замени со еден вид црна капа, изработена од ткаенина, што влијаеше и на тоа да се постигне нејасна идентификација и со Македонците со исламска вероисповед. Новата

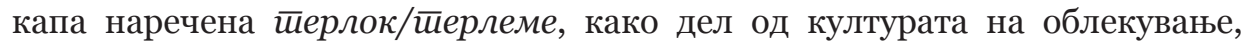
многу бргу почнала да се проширува и да се јавува и во други региони во Македонија ${ }^{2}$, иако никој не знае да ја каже историјата на таквата појава или, пак, од каде доаѓа ваквата капа, а и самите не знаат зошто носат таква капа. Тие не ја чувствуваат како туѓа. За капата постојат различни размислувања. Еден продавач на капи во Старата чаршија во Скопје вели дека капата е грчка ${ }^{3}$, што е неиздржана теорија. Еден универзитетски професор во Турција вели дека ваква капа е забележена во Анадолија и дека се користела „за време на клањање“ и, според него, би требало да е „турска“4. Именката иерлок/tërllok се употребува само во народниот говор и не е прифатена во литературниот албански јазик, а ниту во еден речник или пак енциклопедија не се забележува употребата на ваков збор. Во турскиот јазик се користи терминот takke, што значи капа и служи за апсорбирање на потта по работата за да не им достуди на главата. Таа е изработена од ткаенина, платно или свила (Yilmaz 2010: 622). Етимологијата на зборот укажува на поткапа што се користела за апсорбирање на потта и, вообичаено, ја носеле муслиманите. Ориенталистот Мухарем Јахја го дава зборот иеерлок како спој од два елемента: ter, што на турски јазик значи „пот“ и наставката $-l l k /$ llëk/-lëk, што означува средство за нешто. Кај Македонците со исламска вероисповед се користи токму именката иеерлеме/тур. terleme, што значи „пот“; коренот на зборот и во македонскиот и во албанскиот јазик е ист. Но сепак е проблематично прашањето за семантиката на лексемата иеерлок/ tërllok, поточно на формата иеерлеме, која се употребува во турскиот јазик со значење „испотеност“, но не во врска со капа (Кorçа 2009: 555). Називите иеерлок или иеерлеме имаат преносно значење и можно е во албанскиот јазик да се само јазична калка. Чудно е што досега не сум нашла нешто

2 Треба да се нагласи дека трелеме носат во Скопје, Тетово, Гостивар и Куманово, но не е познато како дел од облековната култура во Дебар, Кичево, Струга, Ресен и Битола.

3 Според информациите од еден продавач на капи од Скопје, терлемето претставува грчка капа и го носеле еснафите, богатите и има грчка припадност како што му кажал еден од најстарите терзии во градот, којшто понекогаш и самиот го носел онака од ќеф, додека минувачите го поздравувале со турскиот поздрав „мерхаба“, мислејќ́ дека е муслиман поради капата, терлокот/трлемето, што ја носел. Честопати, самиот тој изјавувал дека „капата е негова“ во смисла на верската припадност. Ваквите информации остануваат на ниво на шпекулации, без можност да се докажат. Интервју со Абдилмеџит Мустафа, роден во 1949 г. Интервјуто е реализирано на 3 октомври 2016 г. од Букурије Мустафа и Рини Усеини во дуќанот „Шапкар“ во скопската Стара чаршија.

4 Хакан Туркан, „Кarabük Üniversitesi“, сектор: Историја. 
напишано за овој вид капа. Во некои други извори, каде што станува збор за народната носија од Динарскиот Регион, се вели дека народите од Хрватска и од Босна носеле повисоки капи, во темноцрвена боја, и под нив носеле бели ленени капи или, пак, плетени со кука и од памук, и овој вид поткапа е познат под името чулах или бјелокай ${ }^{5}$. Покрај црната капа што е позната како चеерлеме или चеерлок, постојат и бели капи со истото име, кои се плетеле со кука или најчесто се донесени од аџилак, како подарок за другите. Најчесто ваква капа носат и помладите при верски обреди.

Модификацијата на народната носија, како и новините и влијанијата се гледаат и во женската носија, којашто постојано се менувала, најверојатно и под влијание на религијата, така што дел од носијата станал црниот мантил, наречен ишерлик. И етимологијата на лексемата иеерлик нема никаква поврзаност со основното значење во турскиот јазик „влечка“. И овој збор не се наоѓа во литературниот албански јазик, но во народниот говор се употребува во смисла на црниот мантил. Според објаснувањето од Абдулах Шкалиќ, во босанската култура се забележува употребата на зборот terluke/terluci со значење женски влечки, изработени од преработена козја црвена кожа (сахтијан) или од кожа во жолта боја (кајсар), одозгора извезени со златен, сребрен или со свилен конец (Škaljić 1966: 612). Во современиот турски јазик terlik се употребува за сите видови влечки (Korça 2009: 555). Терликой е, исто така, и дел од женската носија за жените Македонки со исламска вероисповед, при што не се разликуваат од муслиманските жени Албанки врз основа на црниот мантил, слично со примерот како кај мажите

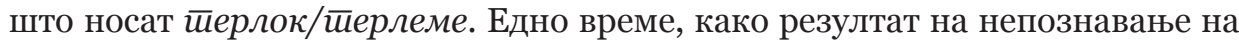
овој крај, како и на луѓето од овие села, не се правеше разлика меѓу нив, туку сите се нарекуваа со едно име, Торбеши.

Има сознанија дека жените во селата некогаш се движеле слободни, облечени во народна носија, непокриени. Така, еден од соговорниците

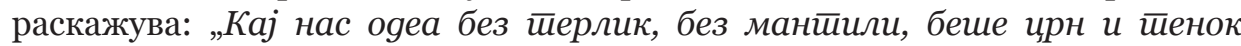
йерлик... можеби и сейа има во селойо... без манииили и со койчиња“б. Ова го спомнува и српскиот етнолог Миленко С. Филиповиќ, кој го посетил овој регион во 1930 г. Тој го посетил селото Патишка и во неговите етнолошки

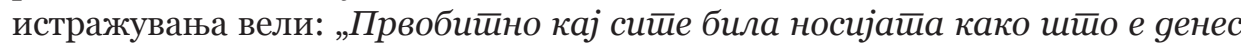
во Река, и муслиманскийе жени не се криеле. Меи́у себе се йосейувале, и муслиманскиие жени не се криеле оg иравославниие мажи. Прво

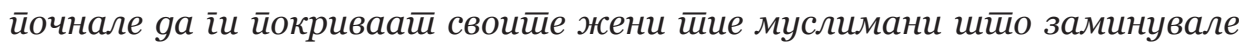
на иечалба во Цариірая и во Бурса. На йочейокой носеле само фереце койа излеі̄увале наgвор оg селойо. Кај ӣравославнииее жени gо неодамна ја имало женскайа реканска носија (йонеког̄аш и сейа ја облекуваай), но

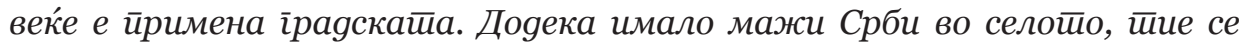

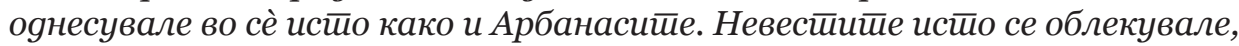

5 Narodni.net/dinarske-narodne-nosnje

6 Интервју со Истреф Беќири, с. Патишка (1928 - 2015), реализирано од Ибе Мустафа и Букурије Мустафа, во Скопје, 15 јануари 2012 г. 


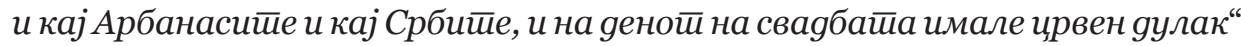
(Филиповић 1931: 169). Етничката припадност во однос на истражувањата конкретно во ова село е проблематична, но реалност е дека не се разликувале воопшто во носијата, па дури и кога станува збор за кечето, што се докажува и на самата фотографија што се наоѓа во студијата „Патишка“ (Филиповић 1931: 166).

Пример дека имаме прифаќање на исламската носија, која се носела од Цариград, е еден друг вид наметка наречена биниш, што била во црвена боја и ја покривала главата и целото тело на невестата, без некој посебен крој, како што ми имаат кажано жените од селото, и што се користела исклучиво на денот кога се земала невестата качена на коњ. Дури во селото Патишка имало само една таква наметка, и таа се пренесувала од една невеста на друга (Mustafa, Murtezani, Useini 2017: 45).

Во времето на османлиското владеење на овие простори, се проширила и употребата на ферецейо и зарой, со што се покажувала муслиманската припадност, како последица од религиозното влијание, и коишто продолжиле да се носат до повоениот период. Разликата меѓу овие две носии луѓето ретко ја препознаваат. Шкалиќ е попрецизен во однос на описот и етимологијата. Фереџето потекнува од арапскиот збор vёredža, и тој го дефинира како вид женска наметка, мантил од црна или модра чоја, што муслиманките го облекувале при излегување на улица. Покрај фереџето, се ставаат и јашмак и чембер, а при подалечни патувања или јавање на

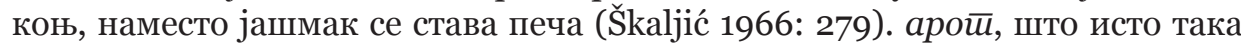
потекнува од арапскиот јазик, има првично значење „завеса“. Тоа е женска наметка со којашто муслиманските жени се завиткувале и така покриени излегувале на улица. Важно е што Шкалиќ нагласува дека многумина ги мешаат фереџето и зарот. Главната разлика го прави материјалот. Зарот се крои од басма, штоф или свила, а фереџето само од чоја (Škaljić 1966: 647). Фереџето се носело и во Средна и Јужна Албанија пред околу 25-30 години од минатиот век, се облекувало или, пак, се носело врз глава со подигнати ракави од мантилот еден врз друг над главата, и така жените излегувале надвор со јашмак на главата (Dizdar 2005: 268). Овој начин на носење на фереџето, наместо да се облече, го олеснувал движењето на жената до некоја блиска дестинација - со покриена глава, додека со рацете покрива дел од лицето со краевите од фереџето.

Иако веќе бил започнат патот на трансформацијата, промените во некои облековни елементи продолжиле да се случуваат преку забрани и одлуки на државната власт, посебно во 50-тите години од XX век, речиси на целата територија на поранешната социјалистичка федерација. Интересни се заложбите, кои започнале во Босна и Херцеговина уште во времето на Кралството Југославија, да се отфрлат фереџето и зарот. Во една статија јасно се зборува за пропаднатите обиди за убедувањето на муслиманската жена во БИХ: на XX конгрес на Антифашистичкиот фронт на жените (АФЖ), кој се одржал во 1947 година во Сараево, е донесена резолуција што ги повикувала муслиманките да го тргнат велот од лицето. Сѐ било 
така средено, жените муслиманки сами да се организираат задолжени да го промовираат ова движење; речиси идентична тактика веќе имала спроведено Комунистичката партија на СССР во своите средноазиски републики. Но акцијата била неуспешна. Еден извештај од подружницата на АФЖ од Власница испратен до сараевската централа покажува дека во текот на собирот во тоа место, по говорот за резолуцијата донесена на конгресот, само една жена го тргнала зарот, иако таа била од „една од најугледните муслимански фамилии во градот"7. Во вакви околности ништо друго не им преостанало, освен да се одлучат за закон со кој ќе се забрани носењето на фереџе и зар. Така, во летото 1950 г., прво било дискутирано на седница на Законодавниот одбор на Народното собрание на Народна Република Босна и Херцеговина, каде што со седницата претседавал Џемал Биједиќ. И на 28 септември истата година, Собранието на НР БИХ го изгласало Законот за забрана на носење на зар и фереџе ${ }^{8}$. По успешноста на донесувањето на законот, акцијата продолжила и во други места каде што живееле муслимани. Во приближно слични околности и во речиси исто време се преземале акции и во Македонија. Веќе било познато дека свештените лица, како што се оџите, ќе можат да ги убедат луѓето дека откривањето на жените не е во спротивност со светите книги. Меѓу тетовското население била одржана конференција од страна на Исламската верска заедница од Тетово на која била разработена изјавата на реиз ул улема на Исламската верска заедница на ФНРЈ и на Улема меџлиси, како и на Исламската верска заедница на PM. На дискусијата се приклучиле и оџите Асан Ефендија и Ремзи Тала. Во своето излагање Асан Ефендија истакнал дека муслиманската вера не проповеда жените муслиманки да носат фереџе („ШАР“ 1950: 3). „На крајот на конференцијата се донесе резолуција во која се вели дека Шиптарите и Шиптарките од нашиот град со радост ја прифаќаат инцијативата на работните Муслимани од НР Босна и Херцеговина, Космет и во другите краишта на нашата Република за симнување на фереџето“ („ШАР“ 1950: 3). Причините за една таква силна акција биле оправдувани со објаснување дека: „со носење фереџе жената Шиптарка останува културно и политички многу назад и со симнување на фереџето ѝ се овозможува да го остави таквиот живот и започне нов посрекен“ („ШАР“ 1950: 3). Законот важел не само за жените Албанки туку и за жените Турчинки, иако се нагласува и се реферира посебно на Албанките муслиманки. По дискусиите и конференциите, на 12 јануари 1951 г. во Народна Република Македонија бил донесен „Закон за забрана да се носи зар и фереџе“. Првиот член од законот гласи: „По сеопшто барање на широките народни маси да се отклони вековниот знак на потчинетоста и културната заостанатост на жената

7 https://vidovdan.org/info/komunisticki-zakon-o-zabrani-zara-i-feredze-od-pre68-godina-i-dalje-vazi-u-bosni- hercegovini/?fbclid=IwARoUTdXJn_yDpCqauBCtZLDWevVFRxo3m7GOsOWgoLYw8plS2oOrl4HgwaI

8 https://vidovdan.org/info/komunisticki-zakon-o-zabrani-zara-i-feredze-od-pre68-godina-i-dalje-vazi-u-bosni- hercegovini/?fbclid=IwARoUTdXJn_yDpCqauBCtZLDWevVFRxo3m7GOsOWgoLYw8plS20Orl4HgwaI 
муслиманка и да се обезбеди полна рамноправност и широко учество во општествениот, културниот и стопанскиот живот на земјата, се забранува носење на зар и фереџе и секое покривање на лицето на жените“ (Службен весник на Народна Република Македонија, бр. 1, 12 јануари 1951 г.). За секое непочитување на овој закон било предвидено лишување од слобода до три месеци или парична казна до 20 ооо динари (Службен весник на Народна Република Македонија, 12 јануари 1951 г., бр. 1, член 3). Ваквата мерка секако влијаела врз отстранувањето на фереџето и зарот, но, пак, ја зачестила интензивната употреба на йерликой. За мене беше големо изненадување кога, при теренското истражување во септември 2016 г., во едно од селата во околината на Велес, Горно Јаболчиште, забележав дека сите жени носеа иерллк од еден постар модел, што го имав видено како дете, а сега повторно го видов, но во едно друго време. Овој модел се состои од два споени дела. Долниот дел е поширок и не е толку долг, се собира на фалти и се врзува со учкур на половината на телото, а горниот дел е делумно споен со долниот, во вид на кошула со ракави и се облекува одгоре, бидејќи сустии (вид копче што се затвора со притискање и спојување на двата дела на копчињата) за закопчување и откопчување има само на горниот дел. Другиот модел на иерлликой е пошироко распространет во однос на употребата. Овој модел е поедноставен, едноделен и сличен на обичниот мантил, и има сусти за закопчување и откопчување. Бојата речиси никогаш не се менува, но кога се употребува за млади невести, се изработува и се везе во различни бои и мотиви, станувајќи дел од народната носија за невестите.

Во рамките на поранешна Југославија, во истиот период се одвивала слична акција и во Косово. Таму, како и насекаде, со отфрлање на фереџето, кај забулените жени се појавил нов начин на облекување, поточно тие започнале со носење на четириаголна шамија, којашто се дипли на спротивните краеви така што се добива триаголен облик, се става на главата, а се врзува под брадата, покривајќи ја косата, што е во согласност со исламското верско учење (се забранува да се види косата на жената). Норвешкиот антрополог Берит Бекер (Berit Backer) престојувала во селото Исниќ во Косово во текот на седумдесеттите години на XX век, во време кога се случувал процесот на промените наметнати од тогашната идеологија и отфрлањето на шамијата. Бекер како антрополог забележува: „Изразот $N u k$ kam havale (I don't have a veil) во општествена смисла значи неслужбена декларација за женското ослободување, кое демонстративно го искажувале помладите девојки. Партијата водела кампања против вистинското фереџе, додека социјалното ослободување за слободно движење во јавната сфера на мажите започнало пред околу десет години од група од пет до шест девојчиња, кои се сега во своите триесетти години, а тогаш оделе на училиште. Наишле на голем отпор во селото, но со поддршка од нивните семејства, инсистирале да го продолжат образованието и на тој начин да ја прошират низ територијата“" (Backer 2003: 40). Бекер во разговор со една жена, која била омажена за член на Комунистичката партија, го претставува уште појасно двојниот менталитет, оној на партијата, како 
и оној на семејството, па и на опкружувањето, како и нивниот меѓусебен судир (Backer 2003: 99-100)9. Употребата на зборот „,havale“ има преносно значење, но во основа значи „прекривање, покривање“, и во носијата таа го има значењето на „забулени“"(Škaljič 1966: 322) ${ }^{10}$.

Влијанијата и промените во носијата и во културата го доведоа во опасност зачувувањето на културното наследство на Албанците, но, и покрај тоа, тие успеаја делумно да ги зачуваат, бидејќи во некои села сѐ уште се носи народната носија, особено во текот на некои од позначајните обичаи и обредите при раѓање, свадба, како и на умирачки, иако полека исчезнува ${ }^{11}$.

Во последно време, во Македонија се актуализира и една друга носија, којашто не е дел од културното наследство на Албанците, ниту е во духот на нивната традиција. Носијата, поточно покривањето на главата и лицето со бурка (фереце) и зар не се ниту национални обележја, но не се ни во духот на верското учење, а секако културолошки се неспојливи и се туѓи.

\section{Заклучок}

Трансформацијата на носијата, како и на целокупното културно наследство би требало да е природен процес што се случува низ времето. Во

9 „Мажот ми подоцна стана член на Партијата, која не беше многу популарна во неговото семејство. Беше исклучен од Партијата во 1953 година, не поради тоа што не се согласуваше со Партијата, туку поради тоа што одби јас да го симнам фереџето. Тој не се осмели поради другите мажи во семејството. Се случуваше членови на Партијата на улица да им ги симнуваат фереџињата насила. Можам да ви кажам дека, многупати, селаните беа близу до крвопролевање. Се сеќавам на првиот пат кога излегов без фереџе. Чувствував дека тоа е најсрамното нешто што сум го направила досега. Но, се навикнувате на тоа. Тоа беше добра реформа.“

10 Havale е арапска лексема и има преносно значење; основното значење е дека се тараби на зидот кое го спречуваат гледањето на соседната авлија или куќа; фиг. „нема хавала меѓу нас“; што значи жените од двете фамилии не се кријат пред мажите. Тоа значи блиски пријатели, бидејќи муслиманските жени се криеле (се покривале) пред туѓите мажи < havale „препуштање, пренесување, спровод: засолниште од гледање, тараби на зидот како препрека за гледање“; < ar. hawala: пренесување, промени.

11 Прашањето на терлокот/терлемето и идентитетот е спомнато и од филозофот Арбер Џафери (Arbër Xhaferi). Тој во својата книга „Nё Tetovë, në kërkim të kuptimit“ вели: „Еден од симболите што го одредуваат националниот идентитет е капата. Ако го смениш тоа, автоматски го менуваш и националниот идентитет. Да речеме, ако еден Албанец прифатеше да ја покрие главата со српска капа, 'шајкача', ќе беше идентификуван од другите како Србин, и обратно, ако еден Србин носеше бело кече, без дилеми ќе беше перципиран како Албанец. Поради ова, ваквите хипотетски можности не се случуваат во реалноста, освен во театарски претстави или филмови каде што костимографијата, преку облеката, ја идентификува етничката припадност на ликовите. Но, чудно е што овие принципи не важат и за позајмувањата од други народи. Многу Албанци не се свесни дека капите што ги носат, познатите терлоци/терлемињата, припаѓаат на семитските народи, на арапските Евреи“. http://koha.net/?id=8\&arkiva=1\&l=98823< : - 31.9.2016.

https://www.akademik.mk/erdogan-ja-ukina-zabranata-za-nosene-shamii-nadrzhavnite-sluzhbenichki-4/ 
историскиот преглед станува појасна ваквата трансформација, која се врзува со други процеси и вредности. Поточно, индивидуата не е само културна единка, таа е дел од една поширока заедница и како таква се развива со своите убедувања, менталитет и свест. Така поврзани, единката и заедницата не прифаќаат промени во однос на традицијата за која се духовно поврзани, но несвесно таа е во постојано менување, развивање и прифаќање на туѓи елементи. Тоа го видовме преку примерот со Турција, која воведе промени во однос на фесот со интенција да прикаже и да изгради модерна држава. Но, спротивно на Ататурк и реформите што тој ги воведе, претседателот Ердоган во поново време направи промени во однос на носењето шамија: „Премиерот Реџеп Таип Ердоган изјави дека се укинува забраната кој била против духот на Турција. Забраната, која беше во сила од 1925-та година,

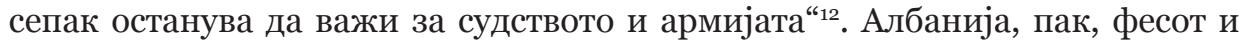
другите османлиски обележја ги сметаше за туѓи и непатриотски, нешто што не одговараше на националниот карактер на државата. Македонија, во рамките на бившите југословенски држави, примени законски одредби за забрана на носење на зар и фереџе, што беше веќе применета пракса во Босна и Херцеговина, во име на изградбата на социјалистичка земја и унапредување на жената во политичкиот и општествениот живот.

Треба да се сфати дека кај луѓето како заедница постои страв дека, ако прифатат да отфрлат некои обичаи или традиција, нема да бидат истите, па можеби оттука потекнува отпорот пројавен тогаш со носијата како верско обележје, а свесни сме дека денес се случува истото со непочитувањето на забраната на одредени обичаи што црквата ги смета за пагански (само како пример, се прекина традицијата за божиќните огнови или пак отстранувањето на мартинките ${ }^{13}$ и др.).

12 https://www.akademik.mk/erdogan-ja-ukina-zabranata-za-nosene-shamii-nadrzhavnite-sluzhbenichki-4/

13 Мартинките се прават со црвен и бел конец кои се испреплетуваат и се ставаат околу раката или закачени на облеката се додека расцвета првото дрво. Верувањата се дека кога ќе расцвета првото дрво, мартинката се закачува на него со желби за здравје на целото семејство. 


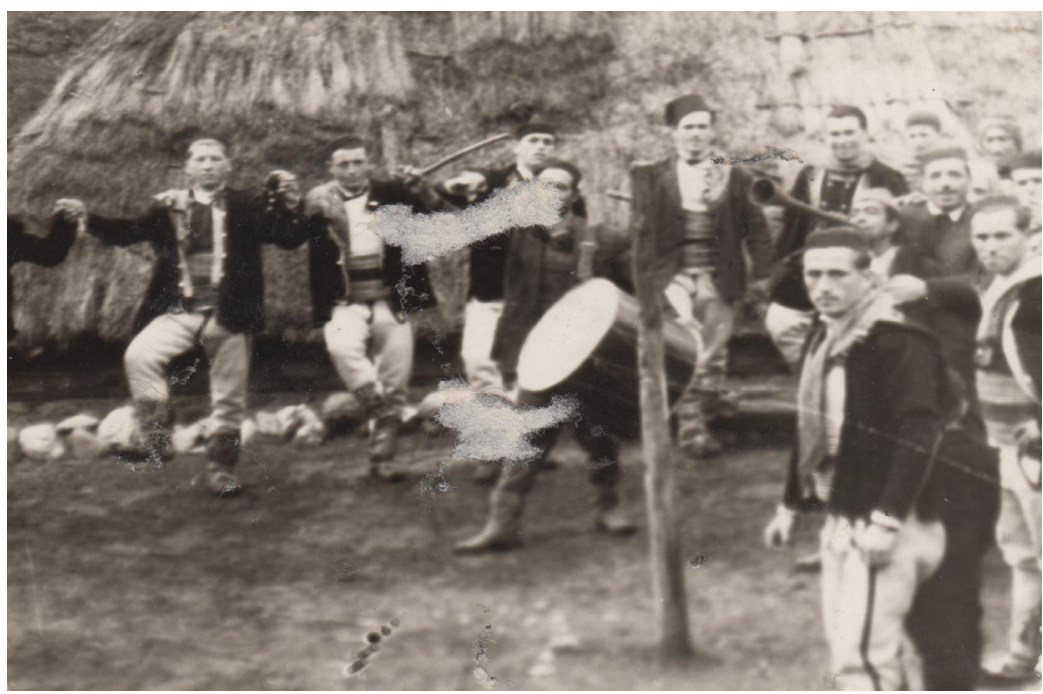

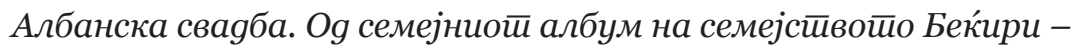
Ериуман Беќири. С. Пайишка, 1963.

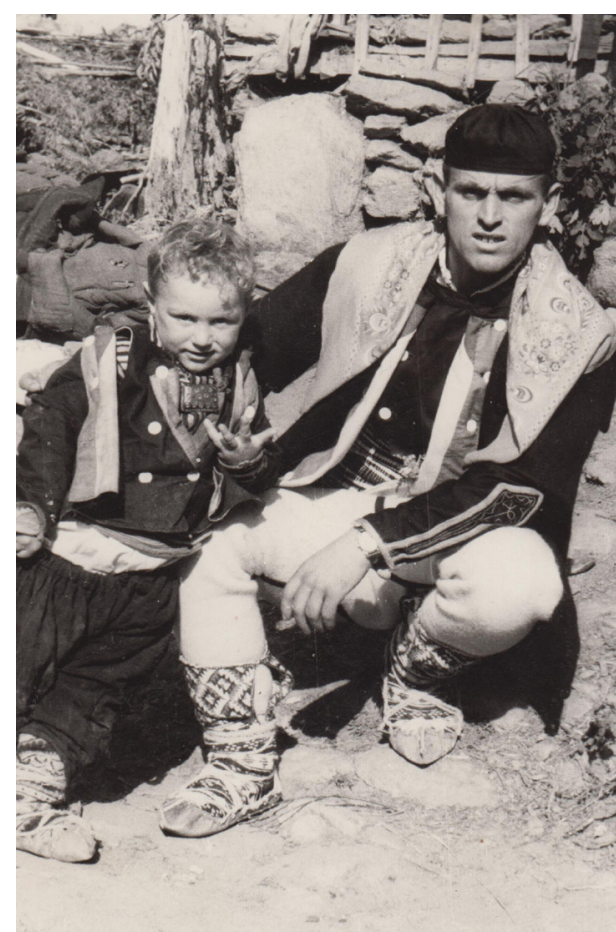

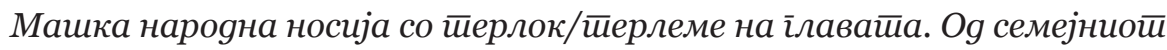

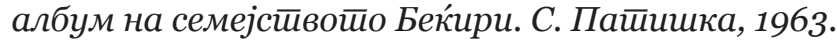


ЕтноАнтропоЗум

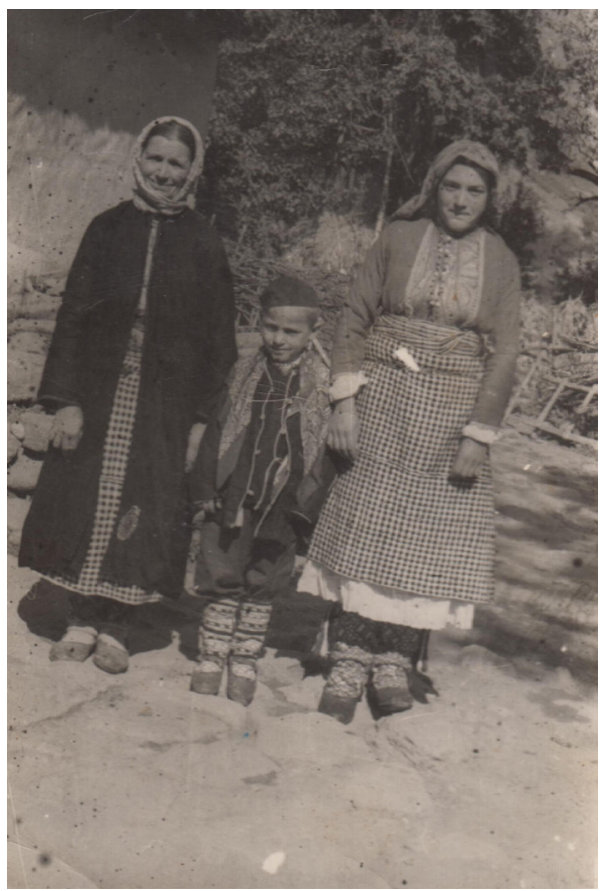

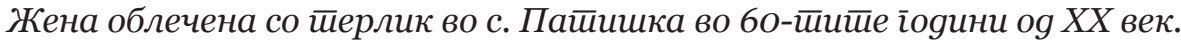

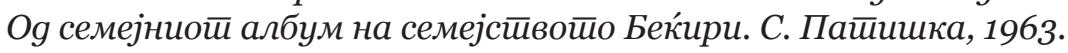




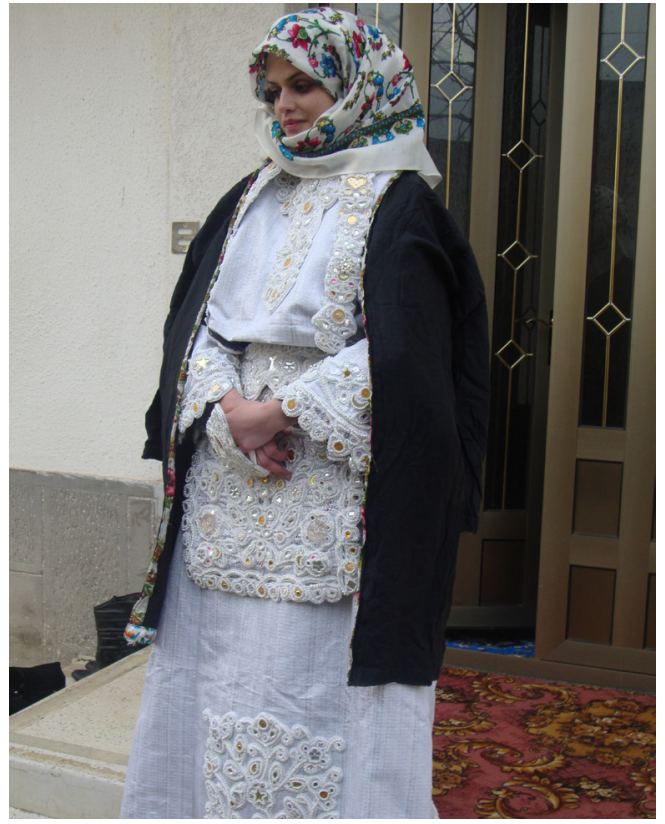

Фойоі̄рафија на носија на невесйа оg Кичево и иеерликой.

С. Шуйово, Кичевско, 2010.

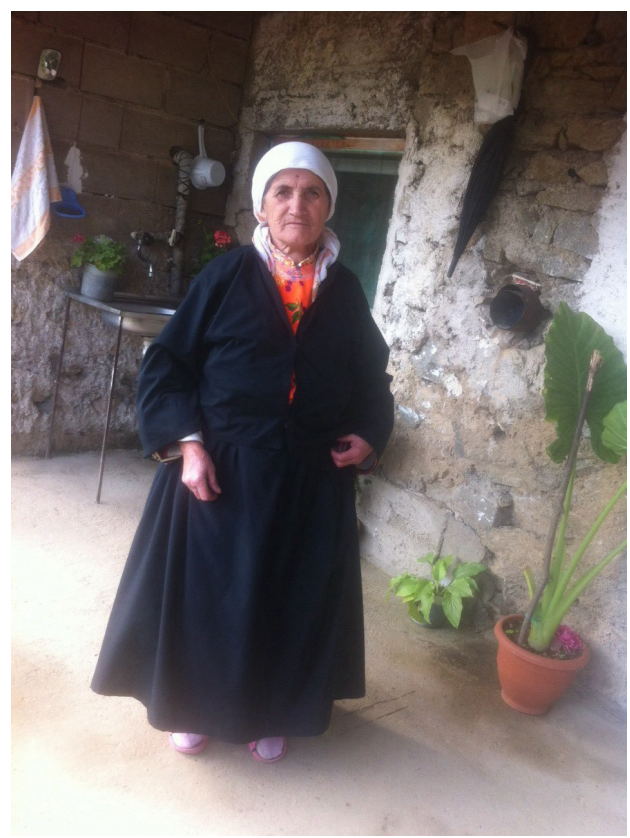

Жена облечена со иеерлик. С. Горно Јаболчишие, околина на Велес, 2016. 


\section{Соговорници}

Истреф Беќири, с. Патишка (1928 - 2015).

Абдул Мустафа, Скопје, 1949.

Хакан Туркан, „Кarabük Üniversitesi“, сектор: Историја.

Мухарем Јахја, ориенталист, Институт за духовно и културно наследство на Албанците.

\section{Извори}

„Закон за забрана gа се носи зар и фереще“,Службен весник на Народна Република Македонија, бр. 1, г. VII, петок, 12 јануари 1951 г.

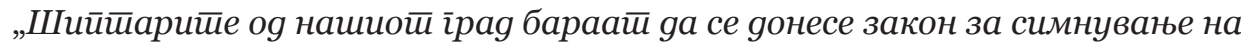
ферецейо“, 8 септември 1950. Весник ШАР-Sharr 3, Тетово.

Комунистички закон о забрани зара и фереџе од пре 68 година и даље важи у Босни и Херцеговини, https://vidovdan.org/info/komunistickizakon-o-zabrani-zara-i-feredze-od-pre-68-godina-i-dalje-vazi-u-bosni-i-hercegovini/?fbclid=IwARoUTdXJn yDpCqauBCtZLDWevVFRxo3m7GOsOWgoLYw8plS20Orl4HgwaI

Ердоган ја укина забраната за носење шамии на државните службенички https://www.akademik.mk/erdogan-ja-ukina-zabranata-za-noseneshamii-na-drzhavnite-sluzhbenichki-4/

Dinarske narodne nošenje“, Narodni.net/dinarske-narodne-nosnje „Në Tetovë, në kërkim të kuptimit“, http://koha. net $/$ ?id $=8 \&$ arkiva $=1 \& \mathrm{l}=98823<$ : 


\section{Литература}

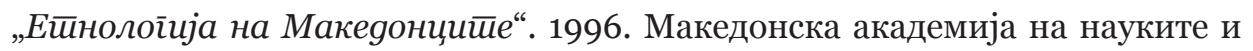
уметностите, Скопје.

Филиповић, Миленко. 1931. „Патишка“, Јужни ӣре̄̃леg 4: 163-174. Скопље.

Asani, Skender. 2013. Gjurmë nëpër kohë. Shkup.

Backer, Berit. 2003. Behind Stone Walls - Changing household organization among the Albanians in Kosova, Peja: Dukagjini Balkan Books.

Dizdar, Tahir. 2005. Fjalor $i$ orientalizmave në gjuhën shqipe. Tiranë: Instituti Shqiptar i Mendimit dhe i Qytetërimit Islam (AIITC).

Gjergji, Andromaqi. 2004. Albanian costumes through the centuries - Origin, types, evolution. Tirana: Academy of Sciences of Albania, Institute of Folc Culture.

Gjergji, Andromaqi. 2005. Veshjet shqiptare në shekuj. Akademia e Shkencave e Shqipërisë, Tiranë: Instituti i Kulturës Popullore.

Ibrahimi, Nexhat. 2017. Fjalor Enciklopedik Islam. Shkup: Logos-A.

Korça, Myxhahid. 2009. Fjalor shqip-turqisht-Arnavutça Sözlük. Shkup: LogosA.

Lubonja, Fatos. 2002. Between the glory of a virtual world and the misery of a real world. Albanian Identities, Myth and History, 91-103. London: Hurst\&Company.

McCarthy, Justin, 2017. Popujt osmanë dhe fundi i Perandorisë. Tiranë.

Mustafa, Bukurije, Murtezani, Izaim, Useini, Rini. 2017. Gjurmëve tëveshjes popullore shqiptare në Maqedoni. Shkup: Instituti i Trashëgimisë Shpirtërore e Kulturore të Shqiptarëve. 
Selimi-Osmani, Edibe. 2012. Veshja autoktone e femrave të Rekës së Epërme; Authentic clothing of women from Reka e Epërme. I, Tetovë. (Bilingual edition).

Skok, Petar. 1971. Etimologijski rječnik hrvatskoga ili srpskoga jezika. Zagreb: Jugoslavenska akademija znanosti i umjetnosti.

Škaljić, Abdulah. 1966. Turcizmi u srpskohrvatskom jeziku. Sarajevo: „Svjetlost“.

Yilmaz, Fehmi. 2010. Osmanl Tarih Sözlüğü. Istanbul: Gökkubbe. 